\title{
$\angle$ Research Square \\ Exposure of Public Sector with the Quasi-Market Through Outsourcing: A Case Study in Iran
}

\author{
Habib Omranikhoo \\ Bushehr University of Medical Sciences \\ Mohammad Azmal \\ Bushehr University of Medical Sciences \\ Hedayat Salari \\ Bushehr University of Medical Sciences \\ Layla Ghorbanalizadeh \\ Bushehr University of Medical Sciences
}

Mehdi Rezaee ( $\square$ m.rezaee8666@yahoo.com)

Kerman University of Medical Sciences, Medical University Campus, Haft-Bagh Highway

\section{Research Article}

Keywords: public - private partnership, public - private cooperation, Outsourcing, quasi-market, outsourced Services.

Posted Date: January 28th, 2022

DOI: https://doi.org/10.21203/rs.3.rs-1298213/v1

License: (ㅇ) (i) This work is licensed under a Creative Commons Attribution 4.0 International License. Read Full License 


\section{Abstract}

Objective: Outsourcing as an effective strategy in public management has brought the attention of policy makers for long time ago. This strategy as a public -private partnership arrangement (PPP) was coined to increase efficiency and quality in public organizations in this study we aimed to investigate the frequency of using common outsourcing models in Bushehr University of Medical Sciences (BUMS).

Methods: This is a descriptive and cross-sectional study conducted in year 2020 in BUMS. Research population was all the deputies, hospitals and health networks affiliated to BUMS. This study was carried out in four stages including: literature review, construction of a checklist, quality assurance of gathered data and finally categorization of the outsourced services.

Result: Results showed that there was a total of 7 various outsourcing models on which 189 cases of services have been outsourced. 108 cases out of 189 were clinical and the rest non-clinical. Among the outsourcing models, Service purchasing model was the commonest used model and two more models including leases and divesture were lack of use.

Conclusion: Results signify that although various outsourcing models are available however, the frequency of outsourced services is still limited, showing that in order to spread the penetration of this strategy it needs to be tackled the obstacles ahead of its successful implementation. Increasing the knowledge of mangers would be definitely an effective solution. Furthermore, capacity -building towards raising the number of private health care providers could facilitate the implementation of outsourcing policy.

\section{Introduction}

Public management has been always criticized for failing to fulfill high quality and one of the most substantial principles of economics, namely efficiency (Alonsoa et al., 2015; Joudaki et al., 2015). In order to cope with this problem or mitigate it, policy makers and researchers have been looking for the best strategies for years (García-Rada, 2011; Mayston, 1999). New public management as a structural reform was a concept and undoubtedly a modern paradigm introduced with the aim of fundamental changes in public bodies and overcoming these problems(Matei \& Chesaru, 2014). High efficiency and quality are two of the most considerable features of good production and services that are just met in a competitive market, as the more competitive a market is, the higher efficiency and quality will arise(Tabibi et al., 2008; Tourani et al., 2010). Thus, policy makers of the new public management field have been perusing initiatives upon which managers could create a quasi -market condition in public sectors (Perrot, 2006a, 2006b; Preker \& Harding, 2003; " Witter S, Ensor T, Thompson R, Jowett M. Health economics for developing Countries: a practical guide. 1th ed. London: MacMillan Education; 2000,"). Outsourcing or contracting out as a public-private partnership (PPP) arrangement has been one of the central strategies in this regard deemed to somewhat could benefit public organizations from the competitive market advantages. Building on this paradigm, providing all or part of the internal activities of a public organization is transferred to a third party or contractor(Billi et al., 2004). Health sector due to using emerging advanced technologies as well as higher inflation rate compared to other public sectors is intrinsically costly and necessitates to head applying efficiency -oriented strategies such as outsourcing(Ferdosi et al., 2010; Motlagh et al., 2008). 
In Iran, outsourcing as a decentralization and market type policy (Fatemi \& Behmanesh, 2012; Motlagh et al., 2008; Preker \& Harding, 2003) gained a lot of attention roughly 15 years ago coincident with the third four-year national development plan bill (Akbari et al., 2012; Barati-Marnani \& Gudaki, 2005). In line with this policy, Iran's Health Ministry asked for its affiliated universities to put into effect this strategy(Gholamzadeh-Nikjoo et al., 2012). Although this policy has undergone some changes with altering the governments, yet with regard to the consensus on its advantages and despite some pessimism derived from unsuccessful experiences(Macinati, 2008), it has always been an alternative strategy for materializing the values of the private sector in public bodies (M Ferdosi et al., 2013; Joudaki et al., 2015). In the current study we aimed to investigate the number of outsourced services with regard to the associated outsourcing models in Bushehr University of Medical Sciences after 15- year ups and downs in implementation of this policy.

\section{Methods}

This is a cross sectional study conducted in Bushehr University of Medical Science in 2020. The research population included deputies, hospitals and health care networks affiliated to Bushehr University of Medical Sciences. This Research was conducted in three stages. In the first stage, in order to extract PPP models, the literature review was done in several databases such as: PubMed, Science direct, Scopus, Magiran (in Persian) and Google Scholar search engine using applied keywords including: outsourcing, contracting out, PPP and their Persian equivalents between 1990-2019 upon which 56 articles and 2 research reports were found. They were refined step by step and finally with regard to the aim of study and after reading titles, abstracts and full texts, 25 articles and two research reports were selected. They were carefully reviewed and finally 7 models for outsourcing services were obtained as shown in table 1(Macinati, 2008; Sadeghi et al., 2016). In the second stage, in order to correspond the outsourced services with their pertained PPP models, a three-part checklist including: name of outsourced contract, kind of outsourced model and kind of outsourced service (clinical, non-clinical) was constructed and sent to the relevant units to complete it. During the third stage, after receiving the completed checklists, in order to ratify and assure the quality of the data recorded in the checklists, two experienced members from the research team randomly contrasted the recorded information in checklists with concluded contracts as a reference.

\section{Results}

The results of the study showed that there were seven common different outsourcing models on which public organizations can materialize PPP arrangements and pave the way for increasing productivity. Name and functions of each model have been elaborated on table 1.

Table1. Classification of common outsourcing models 


\begin{tabular}{|c|c|c|c|c|c|c|c|}
\hline \multirow[t]{2}{*}{ row } & \multirow{2}{*}{$\begin{array}{l}\text { Outsourcing } \\
\text { models }\end{array}$} & \multirow[t]{2}{*}{ Definitions } & \multicolumn{3}{|c|}{ Number of outsourced services } & \multirow{2}{*}{$\begin{array}{l}\text { Total } \\
\text { suitable } \\
\text { services for } \\
\text { outsourcing }\end{array}$} & \multirow{2}{*}{$\begin{array}{l}\text { Percentage } \\
\text { of } \\
\text { outsourced } \\
\text { services }\end{array}$} \\
\hline & & & Clinical & Nonclinical & Total & & \\
\hline 1 & $\begin{array}{l}\text { Service } \\
\text { purchasing }\end{array}$ & $\begin{array}{l}\text { Based on this } \\
\text { model, In return } \\
\text { for receiving } \\
\text { certain } \\
\text { services, the } \\
\text { Public sector } \\
\text { will pay a } \\
\text { private } \\
\text { contractor. }\end{array}$ & 77 & 81 & 158 & 310 & 50.97 \\
\hline 2 & $\begin{array}{l}\text { Management } \\
\text { outsourcing }\end{array}$ & $\begin{array}{l}\text { With regard to } \\
\text { this } \\
\text { outsourcing } \\
\text { model, } \\
\text { management } \\
\text { of a public } \\
\text { body or } \\
\text { department } \\
\text { with the aim of } \\
\text { increasing } \\
\text { efficiency and } \\
\text { quality is } \\
\text { delegated to a } \\
\text { qualified } \\
\text { person or team } \\
\text { whether or not } \\
\text { inside or } \\
\text { outside the } \\
\text { public facility. }\end{array}$ & 1 & 0 & 1 & 5 & 20 \\
\hline 3 & $\begin{array}{l}\text { Cooperative } \\
\text { outsourcing }\end{array}$ & $\begin{array}{l}\text { Upon this } \\
\text { model, both } \\
\text { sides of } \\
\text { contract are } \\
\text { committed to } \\
\text { providing } \\
\text { resources } \\
\text { needed for } \\
\text { delivering } \\
\text { services. Share } \\
\text { of each side } \\
\text { from expected } \\
\text { profits and } \\
\text { other details is } \\
\text { explicitly } \\
\text { embedded in } \\
\text { contract. }\end{array}$ & 14 & 0 & 14 & 25 & 56 \\
\hline 4 & $\begin{array}{l}\text { Leases } \\
\text { contract }\end{array}$ & $\begin{array}{l}\text { Upon this } \\
\text { model, Private } \\
\text { sector rents a } \\
\text { public facility } \\
\text { or a } \\
\text { department. In } \\
\text { return for this } \\
\text { contract, } \\
\text { private firm }\end{array}$ & 0 & 0 & 0 & 0 & NA \\
\hline
\end{tabular}




\begin{tabular}{|c|c|c|c|c|c|c|c|}
\hline & & $\begin{array}{l}\text { acquires the } \\
\text { right of } \\
\text { collecting } \\
\text { revenues and } \\
\text { employing } \\
\text { human forces. } \\
\text { Public sector } \\
\text { may be } \\
\text { responsible for } \\
\text { providing } \\
\text { capital } \\
\text { equipment. }\end{array}$ & & & & & \\
\hline 5 & $\begin{array}{l}\text { Complete } \\
\text { outsourcing }\end{array}$ & $\begin{array}{l}\text { According } \\
\text { to this } \\
\text { model, The } \\
\text { government } \\
\text { pays } \\
\text { private firm } \\
\text { to manage } \\
\text { and provide } \\
\text { the required } \\
\text { services in } \\
\text { a public } \\
\text { health } \\
\text { facility. } \\
\\
\text { Private } \\
\text { sector } \\
\text { (firm) is } \\
\text { committed } \\
\text { to } \\
\text { employing } \\
\text { staff and } \\
\text { providing } \\
\text { logistic } \\
\text { services } \\
\text { and all the } \\
\text { required } \\
\text { equipment. }\end{array}$ & 14 & 0 & 14 & 80 & 17.50 \\
\hline 6 & $\begin{array}{l}\text { concession } \\
\text { contract }\end{array}$ & $\begin{array}{l}\text { Within the } \\
\text { framework of } \\
\text { this model, } \\
\text { public sector } \\
\text { grants a } \\
\text { concession to } \\
\text { a private } \\
\text { company to } \\
\text { finance, build, } \\
\text { operate and } \\
\text { transfer or not } \\
\text { a health facility } \\
\text { to a public } \\
\text { sector. } \\
\text { BOT and BOO } \\
\text { are two of the } \\
\text { most } \\
\text { prominent }\end{array}$ & 2 & 0 & 2 & 6 & 33.33 \\
\hline
\end{tabular}


models of this

kind.

\begin{tabular}{lll}
\hline Divesture & Based on this \\
contract & model, \\
& ownatization) \\
ownership of a \\
public entity \\
like a hospital \\
is transformed \\
to a private \\
sector. \\
Private sector \\
bears \\
responsibility \\
of delivering \\
services but \\
government \\
supervisorial \\
role is still \\
maintained.
\end{tabular}

$\begin{array}{lllllll}8 & \text { Total } & 108 & 81 & 189 & 426 & 44.37\end{array}$

Finding the study also indicated that a total of 189 cases of service that would be delivered by public sector, are being provided by private sector. 108 out of 189 outsourced cases were clinical and the rest of them nonclinical.

Considering outsourcing models, the results highlighted that the service purchasing model with 158 cases accounted for the maximum share of outsourced services meanwhile the managerial outsourcing model with merely one case had the lowest share in comparison with other used models. Furthermore, the findings underlined that the complete outsourcing and cooperative models with 14 cases had the same proportion of contracted out services (figure \& table 1).

Examining the usage rate of different outsourcing models in non-clinical services indicated that the only used model has been service purchasing and the other models have not been utilized. Yet various models had been used to outsource clinical services. It is noteworthy that two models including leases and divesture contract have not been used whatsoever.

Investigation of the penetration rate of outsourcing models in all hospitals affiliated to Bushehr University of Medical Sciences also implied that nearly $44 \%$ of services included in checklist compatible with outsourcing are now being delivered through PPP and the rest of them are still provided with public sector itself.

\section{Discussion}

Public- private partnership followed by adoption of outsourcing models is a strategy that can fulfill sustainability and increased quality of services in public sector. According to our information based on the latest literature review, this is the first study dealing with the outsourced services and their associated models in Bushehr health care sector.

Findings revealed that the scope of outsourcing of health services included both clinical and non-clinical services. Although this is still a huge gap between the number of contracted out services and the ones 
potentially could be outsourced. This finding is of remarkable importance and showing that if managers are familiar with the objectives and functions of outsourcing, it can be more smoothly spread at the organization level and this notion that clinical services are difficult to be outsourced is declined. In this regard, Sadeghi et al. In their study entitled review of models of PPP in provision of hospital services concluded that the scope of partnership dependent on the studied country encompassed both clinical and non-clinical services and for achieving this goal, several models had been used and this strategy had led to positive outcomes for patients and hospitals (Sadeghi et al., 2016).

Barati et al. in their study (Barati et al., 2017) examined outsourced clinical units and concluded that three PPP models including lease, cooperative and managerial had been used and outcomes have been mostly satisfactory.

In another study researchers revealed that a number of clinical services through managerial model had been delegated and this process resulted in improved access and satisfaction(Tourani et al., 2010).

The results of Ferdosi .et al (M Ferdosi et al., 2013) showed that outsourcing had been utilized for purchasing nursing services and staff's perceptions have been negative towards it. In another research conducted by Ferdosi .et .al they showed that outsourcing has been used for provision of nursing services in ENT and neurosurgery departments using service purchasing model (Masoud Ferdosi et al., 2013).

studies conducted by Khooban et.al and Tourani et.al. Showed that outsourcing has been successfully undertaken for provision of pharmaceutical services and service purchasing has been the used model (Khooban et al., 2013; Tourani et al., 2010). Outsourcing of clinical and non-clinical services as well as its positive and negative consequences has been studied in several more studies (Barati et al., 2019; Chen, 1999; Hsiao et al., 2009; Kahouei et al., 2016; Karimi et al., 2012; Siganporia et al., 2016). and in some cases, the outsourcing model has been mentioned too (Graham et al., 2019; Jannati et al., 2017; Zhiarfar et al., 2014).

Findings the present study also represent that the dominant model has been service purchasing as $84 \%$ of total outsourced services have been finalized using this model. This part of findings is consistent with the results of some studies (Berry et al., 2021; Malovec et al., 2015) .one of the reasons attributed to the high usage of this model is that this model has been using for long time ago and as a result familiarity of managers with the terms and conditions of this type model. Additionally, simplicity in implementation has paved the way for being institutionalized.

From another perspective, obtained results underscore that two models including leases and divesture contract (privatization) have not been yet operationalized which comes to large extent back to the low knowledge of managers and also their conservativeness towards outsourcing. Although legal problems are worth noting (Hayati et al., 2015; Raeissi et al., 2018).

Generally, the conducted researches show that although various models exist to outsource services however, this capacity has not been fully utilized and in most cases one or two models have been considered by policy makers and managers. Low motivation and tendency of managers, lack of complete understanding of outsourcing philosophy, unfamiliarity of managers with common outsourcing models, unsuccessful 
experiences of outsourcing, lack of eligible private provider and weakness in law and regulation are factors that have hindered outsourcing expansion (Mujasi \& Nkosi, 2019; Penton et al., 2020; Shaarbafchizadeh et al., 2020).

Study limitation

Lack of access to the outsourced services annually was a limitation that did not allow us to track the rate of implementation of this policy by years in Bushehr University of Medical Sciences.

\section{Conclusion}

To sum up, the results revealed that nearly $44 \%$ of clinical and non-clinical services embedded in checklist compatible with outsourcing are being provided by private sector in Bushehr University of medical. The practical importance of this study is that using the full capacity of outsourcing policy and maximizing the use of common models, it is possible to contract out the preparation of a large fraction of services to the private sector. Hence it is strongly recommended, educating managers about the philosophy and methods of outsourcing as a priority is embedded in their training courses.

Examination and comparison of outsourcing models in terms of efficiency and quality would be a great subject for next researches.

\section{Abbreviations}

PPP: public -private partnership arrangement, BUMS: Bushehr University of Medical Sciences

\section{Declarations}

\section{Ethics approval and consent to participate}

All data are collected and handled in accordance with the relevant privacy protection guidelines. According to Iran law, the study did not fall under the remit of the Medical Research Involving Human Subjects Act and no approval by a medical ethics committee was necessary. Verbal consent was obtained from respondents who completed a questionnaire anonymously, and their response expressed their willingness to participate. Written consent was obtained from participants to the cognitive interviews

\section{Consent for publication:}

Not applicable

\section{Availability of data and material:}

The datasets generated and analyzed during the current study are not publicly available because they contain information that could compromise the privacy of research participants, but are available from the corresponding author upon reasonable request. 
The authors declare no competing interests.

\section{Funding:}

This research did not receive any specific grant from funding agencies in the public, commercial, or not-forprofit sectors.

\section{Authors' contributions:}

H.O.: Data curation, Methodology, Investigation, Supervision, Validation, Writing - original draft

M.A.: Conceptualization, Data curation, Supervision, Validation, Writing - review \& editing

H.S.: Conceptualization, Data curation, Methodology, Supervision, Validation, Writing - review \& editing.

L.Gh.: Data curation, Methodology, Validation, Writing - review \& editing.

M.R.: Conceptualization, Data curation, Methodology, Project administration, Investigation, Supervision, Validation, Writing - review \& editing.

\section{Acknowledgements:}

We would like to thank all staff responsible for outsourcing in affiliated unites of Bushehr University of Medical Sciences for their generous help in conducting this study.

\section{References}

1. Akbari, F., Joudaki, H., Mahmoudi, M., AkbariSari, A., \& Namazi, A. (2012). Exploring the extent and nature of outsourcing in public hospitals affiliated with Tehran University of Medical Sciences. Health information management, 9(3), 397-405.

2. Alonsoa, J. M., Cliftona, J., \& Díaz-Fuentesa, D. (2015). The impact of New Public Management on efficiency:An analysis of Madrid's hospitals. Health Policy, 119(3), 333-340.

3. Barati-Marnani, A., \& Gudaki, H. (2005). Comparative study on privatization of health care provision on contract basis. J Health Administration, 8(21), 105-110.

4. Barati, O., Dehghan, H., Yusefi, A., \& Najibi, M. (2017). A Study of the Status Before and After Outsourced Pharmacies of Shiraz University of Medical Sciences in 2014: A Short Report. Journal Rafsanjan University Medical Science, 16(7), 691-700.

5. Barati, O., Najibi, M., Yusefi, A. R., Dehghan, H., \& Delavari, S. (2019, Feb 27). Outsourcing in Shiraz University of Medical Sciences; a before and after study. J Egypt Public Health Assoc, 94(1), 13. https://doi.org/10.1186/s42506-019-0010-0

6. Berry, L. L., Letchuman, S., Ramani, N., \& Barach, P. (2021, Aug 11). The High Stakes of Outsourcing in Health Care. Mayo Clin Proc. https://doi.org/10.1016/j.mayocp.2021.07.003

7. Billi, J. E., Pai, C.-W., \& Spahlinger, D. A. (2004). Strategic Outsourcing of Clinical Services: A Model for Volume-Stressed Academic Medical Centers. Health Care Management Review, 29(4), 291-297. 
8. Chen, B. (1999). [Outsourcing. Advantages and disadvantages of these processes with regard to the management from the view of the technical services in a hospital]. Bull Soc Sci Med Grand Duche Luxemb(4), 57-63. (Outsourcing. Vor- und Nachteile eines solchen Prozesses im Hinblick auf die Wirtschaftlichkeit aus der Sicht eines technischen Dienstleisters im Krankenhaus.)

9. Fatemi, M., \& Behmanesh, M. R. (2012). New Public Management Approach and Accountability. International Journal of Management, Economics and Social Sciences, 1(2), 42-49.

10. Ferdosi, M., Farahabadi, E., Mofid, M., Rejalian, F., Haghighat, M., \& Naghdi, P. (2013). Evaluation of outsourcing in nursing services: a case study of kashani hospital, isfahan in 2011. Materia socio-medica, 25(1), 37-39. https://doi.org/10.5455/msm.2013.25.37-39

11. Ferdosi, M., Farahabadi, M. E., Mofid, M., Rejalian, F., Haghighat, M., \& Naghdi, P. (2013). Evaluating the Outsourcing of Nursing Services in Kashani Hospital, Isfahan. Health information management, 9(7), 989996.

12. Ferdosi, M., Farahabadi, S., Rejalian, F., \& Haghighat, M. (2010). Evaluation of Medical Record Services Outsourcing of Ayat o Allah Kashani Hospital. Health information management, 7(4), 658-668.

13. García-Rada, A. (2011). Is Spanish public health sinking? British Medical Journal, 343, d7445.

14. Gholamzadeh-Nikjoo, R., Jabbari-Beyrami, H., Jannati, A., \& Asghari-Jaafarabadi, M. (2012). Prioritizing Public- Private Partnership Models for Public Hospitals of Iran Based on Performance Indicators. Health Promotion Perspectives, 2(2), 251-264.

15. Graham, Y., Hayes, C., Mehrotra, P., Spratt, J., Siddle, K., \& Cox, J. (2019, Apr). Clinicians' perceptions of the quality of outsourced radiology and actions taken around perceived imaging errors in practice. Eur Radiol, 29(4), 1649-1654. https://doi.org/10.1007/s00330-018-5873-5

16. Hayati, R., Setoodehzadeh, F., Heydarvand, S., Khammarnia, M., Ravangard, R., Sadeghi, A., \& Sobhani, G. (2015, Dec). The decision-making matrix of propensity to outsourcing hospital services in Bandar Abbas, Iran. J Pak Med Assoc, 65(12), 1288-1294.

17. Hsiao, C.-T., Pai, J.-Y., \& Chiu, H. (2009, 2009/05/13). The study on the outsourcing of Taiwan's hospitals: a questionnaire survey research. BMC Health Services Research, 9(1), 78. https://doi.org/10.1186/14726963-9-78

18. Jannati, A., Jabbari Beirami, H., \& Mousazadeh, Y. (2017). Designing a Downsizing Model for Hospitals of Tabriz University of Medical Sciences [Research]. Journal of Health, 8(3), 336-349. http://healthjournal.arums.ac.ir/article-1-1253-fa.html

19. http://healthjournal.arums.ac.ir/article-1-1253-fa.pdf

20. Joudaki, H., Heidari, M., \& Geraili, B. (2015). Outsourcing of Hospitals Services: Lessons Learned from the Experience. Journal of Health Based Research, 1(1), 13-23.

21. Kahouei, M., Farrokhi, M., Abadi, Z. N., \& Karimi, A. (2016, Apr). Concerns and hopes about outsourcing decisions regarding health information management services at two teaching hospitals in Semnan, Iran. Health Inf Manag, 45(1), 36-44. https://doi.org/10.1177/1833358316639455

22. Karimi, S., Agharahimi, Z., \& Yaghoubi, M. (2012). Impacts of outsourcing in educational hospitals in Iran: A study on Isfahan University of Medical Sciences-2010. J Educ Health Promot, 1, 25. https://doi.org/10.4103/2277-9531.99959 
23. Khooban, H., Gol, R. E., \& Farkhani, E. M. (2013). Evaluation of Outsourcing of Pharmacy Services to the Private Sector in the Family physician Based Health Centers in Khorasan Razavi Province: An EvidenceBased Approach to Policy Making. Journal of Mashhad Medical Council, 17(1), 23-25. https://www.magiran.com/paper/1435969

24. Macinati, M. S. (2008). Outsourcing in the Italian National Health Service: findings from a national survey. international journal of health planning and management, 23(1), 21-36.

25. Malovec, S. N., Borycki, E. M., \& Kushniruk, A. W. (2015). An evaluation of health information technology outsourcing success. Stud Health Technol Inform, 208, 253-257.

26. Matei, L., \& Chesaru, O. M. (2014). Implementation Guidelines of the New Public Management. Cases of Romania and Sweden. Procedia - Social and Behavioral Sciences, 143, 857-861. https://doi.org/10.1016/j.sbspro.2014.07.490

27. Mayston, D. J. (1999). The Private Finance Initiative in the National HealthService: an unhealthy development in New Public Management? Financial Accountability and Management, 15(3-4), $249-274$.

28. Motlagh, M., Rahbar, M., \& Kabir, M. (2008). Decentralization in Health system of Islamic Republic of Iran. J Shaheed Sadoughi Univ Med Sci, 16(3), 67-72.

29. Mujasi, P. N., \& Nkosi, Z. Z. (2019, Apr). Exploring perceptions, motivations, and practices regarding outsourcing support services by general hospitals in Uganda: A mixed methods study. Int $J$ Health Plann Manage, 34(2), e1272-e1292. https://doi.org/10.1002/hpm.2773

30. Penton, M. E., Otto, C., \& Hammerschlag, M. R. (2020, Jul 13). Outsourcing Microbiology Services in Medical Centers: Is It Worth It? J Pediatric Infect Dis Soc, 9(3), 293-297.

https://doi.org/10.1093/jpids/piz019

31. Perrot, J. (2006a). Different approaches to contracting in health systems. Bulletin of the World Health Organization, 84(11), 859-866.

32. Perrot, J. ( 2006b). Is contracting a form of privatization? Bulletin of the World Health Organization, 84(11), 910-913.

33. Preker, A. S., \& Harding, A. (2003). Innovations in health service delivery: the corporatization of public hospitals. the word bank.

34. Raeissi, P., Sokhanvar, M., \& Kakemam, E. (2018, Oct). Outsourcing in Iranian hospitals: Findings from a qualitative study. Int J Health Plann Manage, 33(4), e1250-e1261. https://doi.org/10.1002/hpm.2619

35. Sadeghi, A., Barati, O., Bastani, P., Daneshjafari, D., \& Etemadian, M. (2016). Strategies to develop and promote public-private partnerships (PPPs) in the provision of hospital services in Iran: a qualitative study. Electron Physician, 8(4), 2208-2214.

36. Shaarbafchizadeh, N., Aghdak, P., \& Sahebi, M. (2020). Outsourcing in Health Facilities: Challenges in Medical University of Isfahan in Focus. Int $J$ Prev Med, 11, 172. https://doi.org/10.4103/ijpvm.IJPVM_196_20

37. Siganporia, P., Astrakianakis, G., Alamgir, H., Ostry, A., Nicol, A. M., \& Koehoorn, M. (2016, Oct). Hospital support services and the impacts of outsourcing on occupational health and safety. Int J Occup Environ Health, 22(4), 274-282. https://doi.org/10.1080/10773525.2016.1227035 
38. Tabibi, S. J., Kakhani, M. J., \& Ehsani-Chimeh, E. (2008). An evaluation of the outsourcing strategy in supportive services in the hospitals affiliated to the Ministry of Health and Medical Education. Journal of Health Administration, 10(30), 59-66.

39. Tourani, S., Maleki, M., Ghodousi-Moghadam, S., \& Gohari, M. R. (2010). Efficiency and Effectiveness of the Firoozgar Teaching Hospital's Pharmacy after Outsourcing, Tehran, Iran. Journal of Health Administration, 12(38), 59-70.

40. Witter S, Ensor T, Thompson R, Jowett M. Health economics for developing Countries: a practical guide. 1th ed. London: MacMillan Education; 2000.

41. Zhiarfar, M., Seyedin, S. H., Tourani, S., Khodayari Zarnaq, R., \& Ayoubian, A. (2014). Impact of Outsourcing Healthcare Services Management on the Quality of these Services. International Journal of Hospital Research, 3(3), 145-148.

http://ijhr.iums.ac.ir/article_7705_ff1ab62a6637a3ae170a1ee648010d15.pdf

\section{Figures}

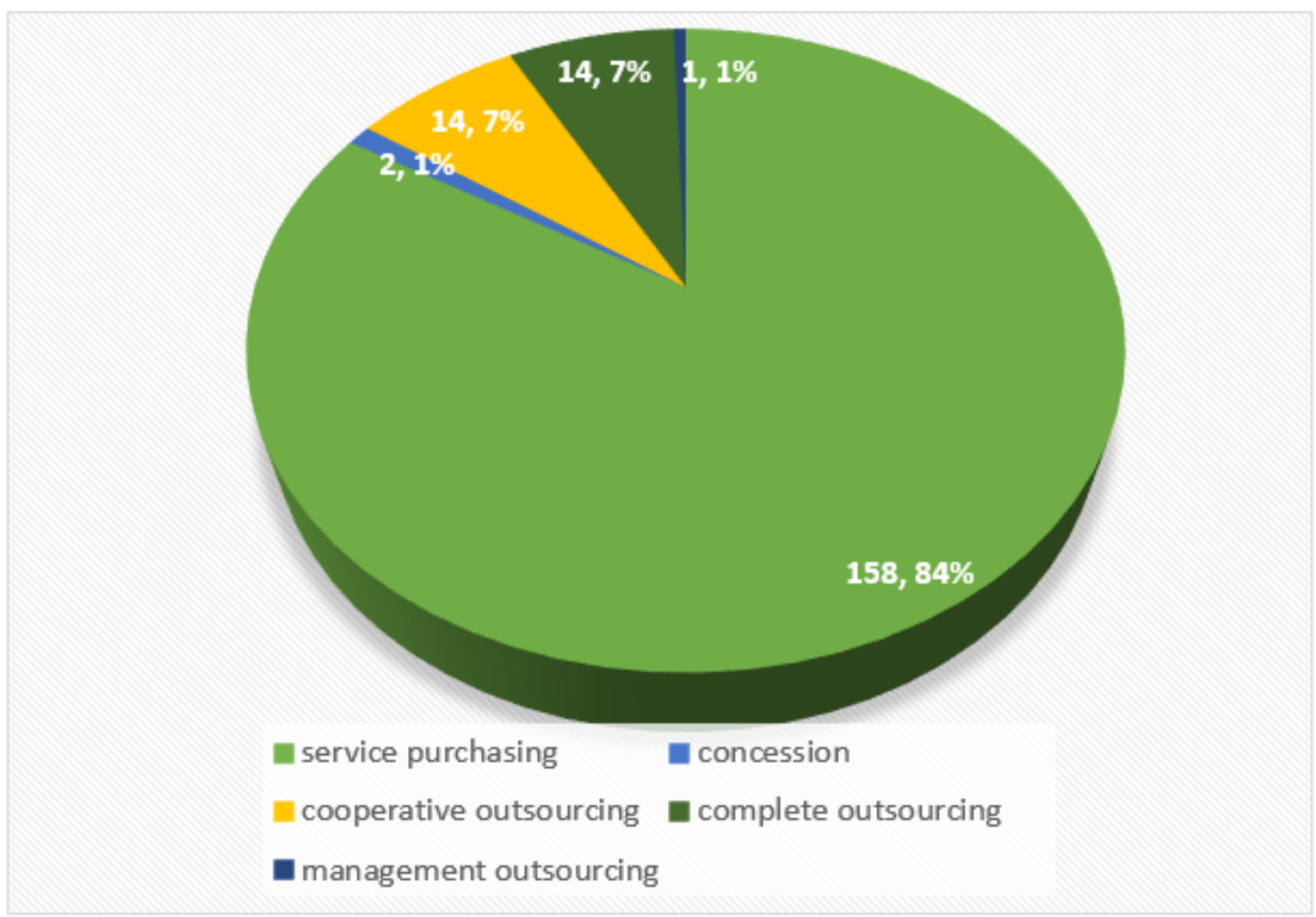

\section{Figure 1}

share of different outsourcing models in outsourced services: 